\title{
Feline cardiac lymphoma: a case report
}

\author{
Linfoma cardíaco felino: relato de caso
}

\author{
Henrique Inhauser Riceti Magalhães* (D), Karen Gonçalves Mendonça², Ygor Henrique de Paula² (D), \\ Fabiano Braz Romão² (D) , Jeferson Borges Barcelos ${ }^{3}$ (1) , Wanessa Ribeiro Gontijo Dobritz ${ }^{4}$, \\ Vera Lucia Pichioni ${ }^{5}$ \& Thaisa Reis dos Santos ${ }^{6}$ (D) \\ 'Veterinary, Doctoral student. Programa de Pós-graduação em Anatomia dos Animais Domésticos e Silvestres, Departamento \\ de Cirurgia, Faculdade de Medicina Veterinária e Zootecnia, Universidade de São Paulo - USP, São Paulo, SP, Brasil \\ Veterinary student. Centro Universitário de Patos de Minas - UNIPAM, Patos de Minas, MG, Brasil \\ ${ }^{3}$ Veterinary student. Fundação Presidente Antônio Carlos - UNIPAC, Uberlândia, MG, Brasil \\ ${ }^{4}$ Veterinary. Independent scholar, Patos de Minas, MG, Brasil \\ ${ }^{5}$ Veterinary. Faculdade de Medicina Veterinária, Centro Universitário de Patos de Minas - UNIPAM, Patos de Minas, MG, Brasil \\ ${ }^{6}$ Veterinary, Dsc. Faculdade de Medicina Veterinária, Centro Universitário de Patos de Minas -UNIPAM, Patos de Minas, \\ MG, Brasil
}

\begin{abstract}
Cancer is the main cause of death among pet animals. FeLV, the feline leukemia virus, increases the odds of domestic felines' developing lymphoma or leukemia 62 fold. The cardiac lymphoma is a rare neoplasia and little is known about it in Veterinary Medicine. Therefore, it has been sought to report a case of cardiac lymphoma in a two-year-old, FeLV-positive feline patient, who presented dyspnea, lack of appetite, progressive loss of weight, and apathy. By means of supplementary examination, the presence of a mass attached to the heat would be verified, and lymphoma was diagnosed upon histopathological examination. It is thus concluded that this neoplasia was associated to the feline leukemia virus and that, in spite of the supplementary examinations' having been utterly important for a correct diagnosis, the lack of an early definition aggravated the clinical picture of the patient and hindered the implementation of specific treatment.
\end{abstract}

Keywords: veterinary medical practice, Felis catus, FeLV, neoplasia, oncology.

\section{Resumo}

O câncer é a principal causa de morte nos animais de companhia. O FeLV, vírus da leucemia felina, aumenta em 62 vezes a chance de felinos domésticos infectados desenvolverem linfoma ou leucemia. O linfoma cardíaco é uma neoplasia rara, e na Medicina Veterinária pouco se sabe sobre ele. Portanto, objetivou-se relatar um caso de linfoma cardíaco em um paciente felino de dois anos de idade e soropositivo para FeLV, que apresentava dispneia, inapetência, emagrecimento progressivo e apatia. Através dos exames complementares foi verificada a presença de uma massa aderida ao coração, diagnosticando-se linfoma a partir do histopatológico. Conclui-se então, que esta neoplasia foi associada ao vírus da leucemia felina e que, apesar dos exames complementares terem sido extremamente importantes para um correto diagnóstico, a sua não definição precoce agravou o quadro clínico do paciente e dificultou a implantação de um tratamento específico.

Palavras-chave: clínica médica veterinária, Felis catus, FeLV, neoplasia, oncologia.

\section{Introduction}

Cancer is the main cause of death among pet animals and accounts for $32 \%$ of the fatalities in domestic felines (Withrow, 2007). Its diagnosis is becoming ever more commonplace in the veterinary clinical practice (Ferraz et al., 2008), partly tied to the ever greater longevity of the animals (Withrow, 2007).

Around 33\% of all tumors in felines are hematopoietic, being most frequently found in domestic cats (Vonderhaar \& Morrison, 1998). The prevalence for that species is superior by comparison to the other domestic species (Court et al., 1997; Gabor et al., 1998).

The malignant proliferation of the lymphocytic cells - originated mainly in lymphoid organs, such as lymph nodes, bone marrow, liver, and spleen - typifies lymphomas. Nevertheless, said development may take place in any other organ due to the ongoing migration of the lymphocytes
How to cite: Magalhães, H. I. R., Mendonça, K. G., Paula, Y. H., Romão, F. B., Barcelos, J. B., Dobritz, W. R. G., Pichioni, V. L., \& Santos, T. R. (2019). Feline cardiac lymphoma: a case report. Brazilian Journal of Veterinary Medicine, 41, e100019. https://doi.org/10.29374/2527-2179.bjvm100019

\section{Financial support: None.}

Conflict of interests: No conflict of interests declared concerning the publication of this article.

Received: September 28, 2018. Accepted: May 25, 2019.

The study was carried out at a private veterinary clinic in Patos de Minas, MG, Brazil.

\section{*Correspondence}

Henrique Inhauser Riceti Magalhães Programa de Pós-graduação em Anatomia dos Animais Domésticos e Silvestres, Departamento de Cirurgia, Faculdade de Medicina Veterinária e Zootecnia, Universidade de São Paulo - USP Av. Prof. Dr. Orlando Marques de Paiva, 87, Campus da Capital,

CEP 05508-270 - São Paulo (SP), Brasil E-mail: henrique123magalhaes@yahoo.com.br 
to the various parts of the body (Daleck et al., 2008). In regard of the chest cavity lymphomas, they are more frequent in the thymus, although they may also be observed in the sternal lymph nodes and by the mediastinum (Holzworth, 1987).

Cardiac neoplasia is extremely rare in cats (Buchanan, 1992). A query in the Veterinary Medical Database, pertinent to the years between 1982 and 1993, revealed that, from a total of 210,388 cats examined, only 58 would present cardiac tumors (0.027\%), lymphoma being the most common diagnosis (Tilley \& Goodwin, 2002).

The feline leukemia virus (FeLV) performs directly in the tumor genesis, whilst increasing the odds of infected domestic felines' developing lymphoma or leukemia 62 fold when compared to non-infected animals (Hartmann, 2012). Though regarded as an oncogenic virus, the development of the neoplasias accounts for just about 10 to $25 \%$ of the fatalities linked to the disease (Sparkes \& Papasouliotis, 2012).

In the heart, the lymphoma is a rarely; yet, little is known of its diagnosis, treatment, and prognosis in Veterinary Medicine (Sims et al., 2003; MacGregor et al., 2005). In light of that, it has been sought to report a case of cardiac lymphoma in an FeLV-positive feline patient.

\section{History}

A female feline, with two years of age, weighing three kilos, of a non-defined breed, and castrated, had been referred for treatment in a private veterinary clinic in the city of Patos de Minas/MG-Brazil, upon complaints of apathy, lack of appetite, and progressive weight loss over nearly 15 days. In consultation, the guardian of the animal produced the results of a hemogram performed three days earlier, and the values were within the range deemed as normal for the species.

The patient was subject to clinical examination as per that which is proposed by Feitosa (2014), and the vital parameters were within normality, except for the respiratory and cardiac rates, which were found to be increased. Apart from that, dyspnea was observed and, upon auscultation of the heart region, a muffling was found.

Subsequently, a radiographic examination of the chest had been performed in the ventral-dorsal and right \& left lateral positions, which revealed pleural effusion and a general increase in radiopaqueness. The procedure of thoracocentesis was performed with aims at providing respiratory comfort to the patient, though with a small amount of liquid drained. The echocardiogram had been conducted from a Phillips (HD-7) device, with a 3-8 MHz sector transducer, which confirmed the presence of free liquid in the thoracic cavity and highlighted the existence of a major heterogeneous structure attached to the heart (Figure 1).

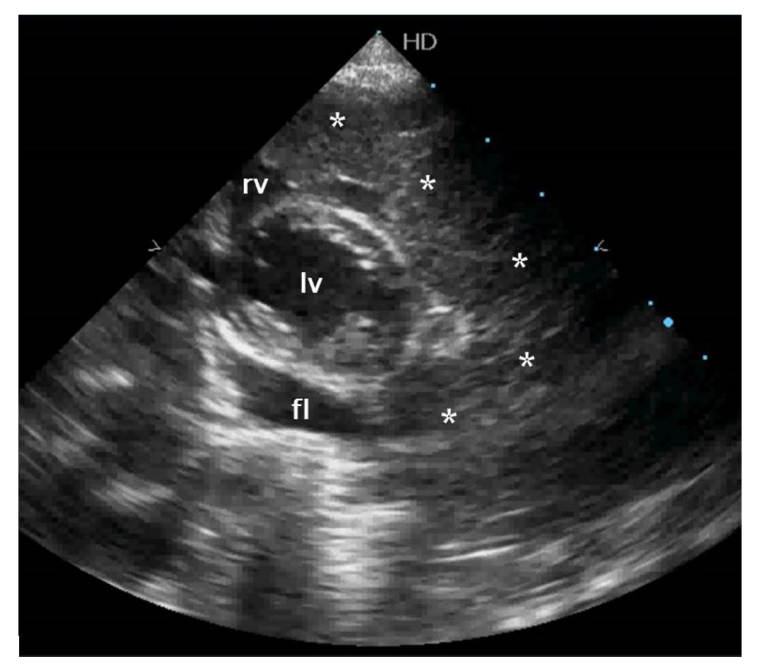

Figure 1. Right transversal parasternal view in echocardiographic examination, highlighting the presence of a large structure $\left(^{*}\right)$ attached to the heart. Other structures referenced: right ventricle (rv) and left ventricle (lv). Note the presence of free liquid (fI) in the thoracic cavity. 
The feline had been subject to a serology test with the Alere ${ }^{\mathrm{TM}}$ FIV Ac/FeLV Ag Test Kit, for the qualitative and simultaneous detection of the IgG antibodies of the feline immunodeficiency virus (FIV) and antigens of the feline leukemia virus (FeLV) through full blood samples, which resulted positive for FeLV.

Intravenous support treatment had been instated with fluid therapy at a dosage of $50 \mathrm{ml} / \mathrm{kg} / \mathrm{day}$ (0.90\% Sodium Chloride solution), Tramadol at $1 \mathrm{mg} / \mathrm{kg}$ at every eight hours, Dipyrone at $25 \mathrm{mg} / \mathrm{kg}$ at every eight hours, and Bionew ${ }^{\circledR}$ at $0.2 \mathrm{ml} / \mathrm{kg}$ at every 24 hours.

The patient was forwarded to exploratory surgery in accordance with the technique proposed by Fossum (2014), with aims at the exclusion of the differential diagnosis of diaphragmatic hernia. A wide tricotomy of the abdominal ventral and of the thoracic lateral \& ventral regions was performed, with the subsequent antisepsis of that area with 1\% Chlorhexidine. The anesthetic induction was carried out intravenously with Propofil at $5 \mathrm{mg} / \mathrm{kg}$, and the general anesthetic maintenance with inhaled Isoflurane. The thoracic opening revealed a significant amount of free liquid and, also, a large mass attached to the cardiac bottom (Figure 2). During the suction of the intrathoracic liquid, the animal had a cardiopulmonary arrest and died.

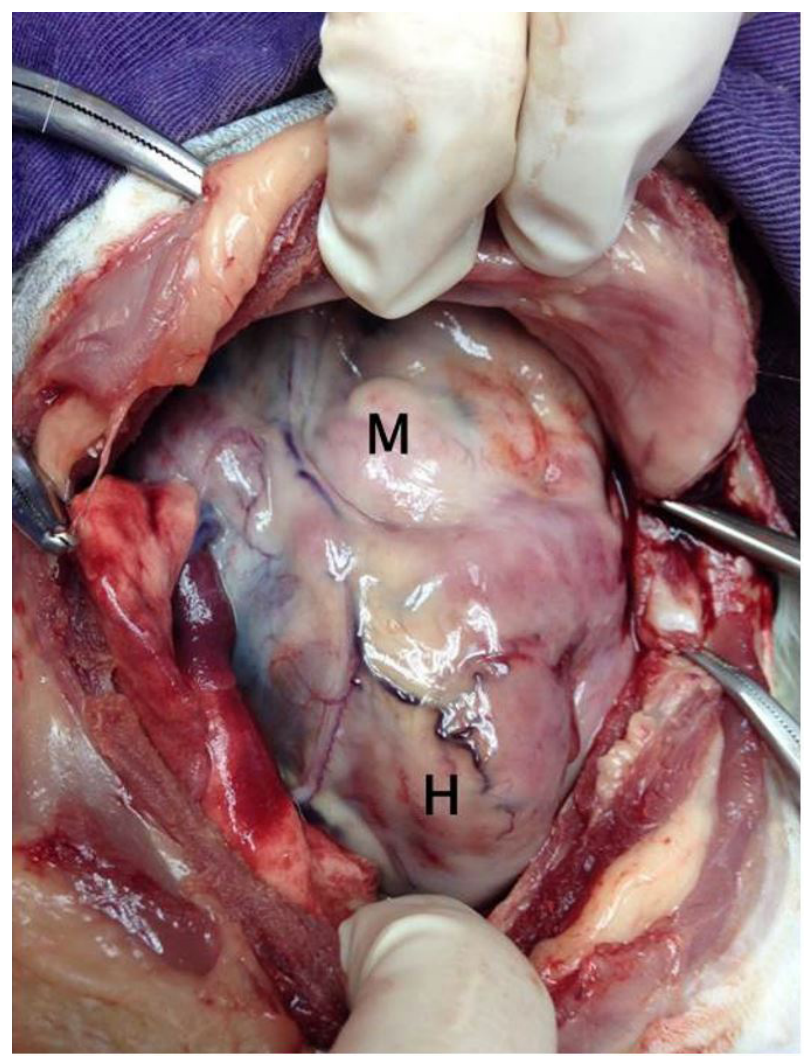

Figure 2. Macroscopic view of the mass $(\mathrm{M})$ attached to the heart $(\mathrm{H})$ after opening of the thoracic cavity.

A sample of the mass was harvested, conditioned into a vial containing aqueous solution of formalin at 10\% and, subsequently, forwarded to histopathological analysis. Macroscopically, the fragment appeared brownish, with a soft and uneven surface. Microscopically, an atypical lymphoid proliferation was observed, characterized by small round cells, plasmacytic in aspect, with peripheral hypercolor nuclei - some of them cleaved - and scarce eosinophilic cytoplasm. Numerous apoptotic cells and rare figures of mitosis were also viewed. As from the analysis performed, the diagnosis of lymphoma was defined (Figure 3). 

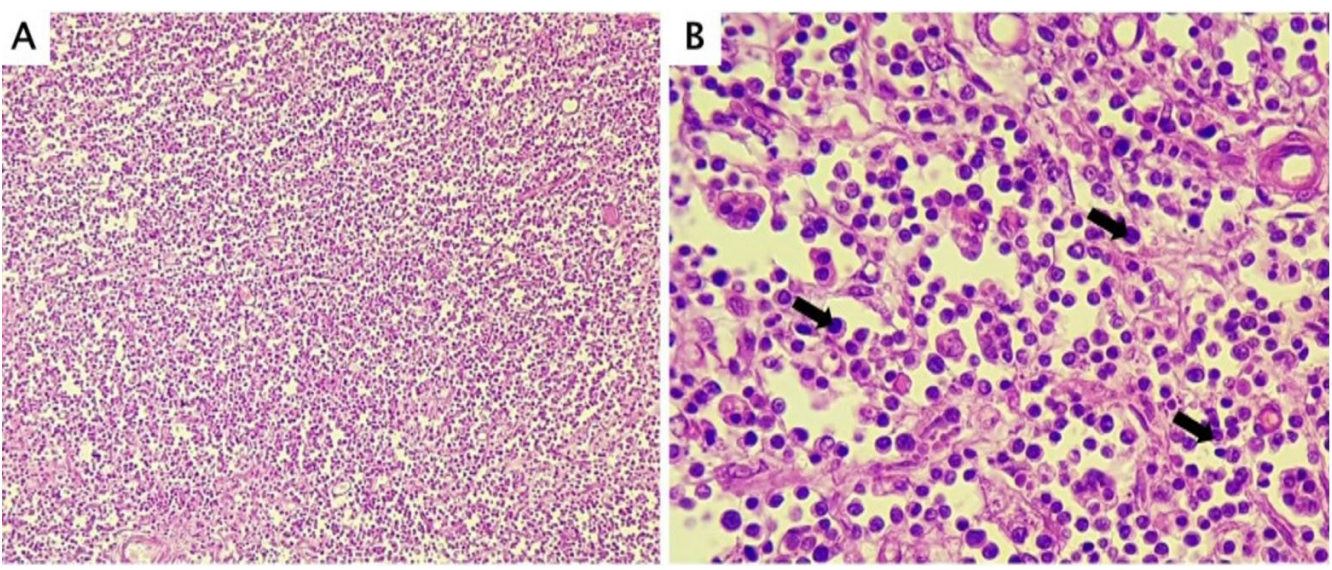

Figure 3. Microscopic view of the mass; Hematoxylin and Eosin staining. (A) Atypical lymphoid proliferation (10x); (B) Examples of lymphoid proliferation characterized by small round cells, with peripheral hypercolor nuclei and scarce eosinophilic cytoplasm (arrows) (40x).

\section{Discussion}

In this report, a cardiac lymphoma was diagnosed in a female feline of non-defined breed, with two years of age. In accordance with the literature, this type of neoplasia is rarely occurring in felines (Buchanan, 1992) and, hence there is not much data in regard of the matter, it is believed that a predisposition of gender or race is non-existent for this disease. According to Ettinger (2003), Vail (2007), and Taylor et al. (2009), cats which have mediastinal lymphoma are often young and FeLV-positive.

In this report, the patient was FeLV-positive and presented dyspnea as the most serious clinical sign. Eleutério (2014) reported the occurrence of a lymphoma around the cardiac bottom of a three-year-old male feline who was also tested positive for FeLV; Amati et al. (2014) reported pericardial lymphoma in seven felines with an average of five years of age, being only one negative for FeLV; Anai et al. (2013) reported a primary cardiac lymphoma in a bitch with eight years of age; and Cápua et al. (2005) reported a mediastinal lymphoma in a two-year-old male feline. In all of the reports considered, the symptomatologic picture of the animals would be similar to that of the feline in this report. The manifestation of apathy, anorexia, and loss of weight observed in this report also corroborate the findings of Cápua et al. (2005), Anai et al. (2013), Amati et al. (2014) and Eleutério (2014). The acute onset of regurgitation or cough is also normally observed in felines with mediastinal lymphoma (Couto, 2000). Other clinical signs described include intolerance to exercise or reluctance to move, tachypnea and dyspnea, cyanosis, dehydration, weak femoral pulse, syncope and cachexia (Cardoso et al., 2004; Amati et al., 2014).

The dyspnea observed in the patient under debate had been a result of the picture of pleural effusion, and it was subject to the technique of thoracocentesis, which aimed at its overall stabilization so the diagnostic and surgical procedures could be performed. The neoplasias are important causes of pleura effusion in small-sized animals (Alleman, 2003) and they must be deemed as a medical emergency, hence they reveal the presence of some severe affection which poses a risk to the health of the animal (Souza, 2013).

Radiography was the first imagery examination performed, as pointed out by Holzworth (1987). The presence of the mass and the dorsal deflection of the trachea - important alterations for the suspicion of intrathoracic neoplasia (Holzworth,1987) - have not been identified in the patient of this report, upon the presence of pleural effusion. A more directed diagnosis was possible after echocardiography was resorted.

In respect of the tumoral relation with the FeLV, Mackey (1975) believes that this virus is responsible for the occurrence of several hematopoietic neoplasias in cats, being regarded as the main causing agent of feline lymphoma in the European and the North-American continents (Court et al., 1997). Helfand \& Vail (1998) believe that 70\% of the feline lymphomas have their cause associated to the feline leukemia virus, even in spite of there being a high rate of lymphomas in FeLV-negative cats (Sherding, 2008). 
The diagnosis of cardiac lymphoma was reached through histopathological examination, which, in accordance with Morrison (2005), is the only means of classifying the tumor properly, even if the fine-needle aspiration biopsy may also render conclusive diagnosis. Such exam, when compared to histology, presents high accuracy in the diagnosis of neoplasias in dogs and cats (Ménard et al., 1986; Ghisleni et al., 2006), but it could not be performed due to the low amount of liquid harvested in the procedure of thoracocentesis.

In cats, and in dogs as well, due to its being a systemic disease, chemotherapy is the treatment of choice for the majority of the presentations of lymphoma (Ettinger, 2003), and most patients attain full remission and present good quality of life (Vail et al., 1998). However, the therapeutic protocol used is not the most important prognostic factor but, rather, the concomitant infection by the feline leukemia virus (Jarrett, 1975), which could have been a determining factor for the non-survival of the animal in question.

\section{Conclusion}

The cardiac lymphoma was associated to the feline leukemia virus and, in spite of the complementary exams' having been utterly important for a correct diagnosis, the lack of an early definition of the same aggravated the clinical picture of the patient and hindered the implementation of a specific treatment.

\section{References}

Alleman, A. R. (2003). Abdominal, thoracic, and pericardial effusions. The Veterinary Clinics of North America. Small Animal Practice, 33(1), 89-118. http://dx.doi.org/10.1016/S0195-5616(02)00057-8. PMid:12512378.

Amati, M., Venco, L., Roccabianca, P., Santagostino, S. F., \& Bertazzolo, W. (2014). Pericardial lymphoma in seven cats. Journal of Feline Medicine and Surgery, 16(6), 507-521. http://dx.doi.org/10.1177/1098612X13506199. PMid:24108202.

Anai, L. A., Jark, P. C., Terra, E. M., Gava, F. N., Marinho, F. A., Calazans, S. G., Costa, M. T., \& Santana, A. E. (2013). Linfoma cardíaco primário em cão. Semina: Ciências Agrárias, 34(5), 2375-2380. http://dx.doi. org/10.5433/1679-0359.2013v34n5p2375.

Buchanan, J. W. (1992). Causes and prevalence of cardiovascular disease. In R. W. Kirk \& J. D. Bonagura. Kirk's current veterinary therapy XI: small animal practice (pp. 647-655). Philadelphia: WB Saunders.

Cápua, M. L. B., Nakage, A. P. M., Ziliotto, L., Coelho, P. S., \& Santana, A. E. (2005). Linfoma mediastinal em felino persa - relato de caso. Ars Veterinária, 21(3), 311-314. http://dx.doi.org/10.15361/2175-0106.2005v21n3p311-314.

Cardoso, M. J. L., Machado, L. H. A., Moutinho, F. Q., \& Padovani, C. R. (2004). Sinais clínicos do linfoma canino. Archives of Veterinary Science, 9(2), 19-24. http://dx.doi.org/10.5380/avs.v9i2.4059.

Court, E. A., Watson, A. D. J., \& Peaston, A. E. (1997). Retrospective study of 60 cases of feline lymphosarcoma. Australian Veterinary Journal, 75(6), 424-427. http://dx.doi.org/10.1111/j.1751-0813.1997.tb14347.x. PMid:9247693.

Couto, C. G. (2000). Advances in the treatment of the cat with lymphoma in practice. Journal of Feline Medicine and Surgery, 2(2), 95-100. http://dx.doi.org/10.1053/jfms.2000.0079. PMid:11716600.

Daleck, C. R., Calazans, S. G., \& Denardi, A. B. (2008). Linfomas. In Daleck C.R., Denardi A.B. \& Rodaski S. Oncologia em cães e gatos (pp. 482-505). São Paulo: Roca.

Eleutério, D. A. S. (2014). Linfoma relacionado ao vírus da leucemia felina (VLF) - relato de caso. Nucleus, 11(2). http://dx.doi.org/10.3738/1982.2278.1354.

Ettinger, S. N. (2003). Principles of treatment for feline lymphoma. Clinical Techniques in Small Animal Practice, 18(2), 98-102. http://dx.doi.org/10.1053/svms.2003.36623. PMid:12831069.

Feitosa, F. L. F. (2014). Semiologia veterinária: a arte do diagnóstico (3. ed., 640 p.). São Paulo: Roca.

Ferraz, J. R. S., Roza, M. R., Caetano Junior, J., \& Costa, A. C. (2008). Hemangiossarcoma canino: revisão de literatura. Jornal Brasileiro de Ciência Animal, 1(1), 35-48.

Fossum, T. W. (2014). Cirurgia de pequenos animais (4. ed., 1619 p.). Rio de Janeiro: Elsevier.

Gabor, L. J., Malik, R., \& Canfield, P. J. (1998). Clinical and anatomical features of lymphosarcoma in 118 cats. Australian Veterinary Journal, 76(11), 725-732. http://dx.doi.org/10.1111/j.1751-0813.1998.tb12300.x. PMid:9862061.

Ghisleni, G., Roccabianca, P., Ceruti, R., Stefanello, D., Bertazzolo, W., Bonfanti, U., \& Caniatti, M. (2006). Correlation between fine-needle aspiration cytology and histopathology in the evaluation of cutaneous and subcutaneous masses from dogs and cats. Veterinary Clinical Pathology, 35(1), 24-30. http://dx.doi.org/10.1111/j.1939-165X.2006. tb00084.x. PMid:16511787.

Hartmann, K. (2012). Clinical aspects of feline retroviruses: a review. Viruses, 4(11), 2684-2710. http://dx.doi. org/10.3390/v4112684. PMid:23202500.

Helfand, S. C., \& Vail, D. M. (1998). Sistema hematopoético. In D. Slatter. Manual de cirurgia de pequenos animais (2. ed., Vol. 2, pp. 2505-2512). São Paulo: Manole. 
Holzworth, J. (1987). Diseases of the cat - medicine and surgery (Vol. 1, pp. 428-439). Philadelphia: W. B. Saunders Company.

Jarrett, W. F. H. (1975). Cat leukemia and its viruses. Advances in Veterinary Science and Comparative Medicine, 19, 165-193. PMid:174410.

MacGregor, J. M., Faria, M. L., Moore, A. S., Tobias, A. H., Brown, D. J., \& Demorais, H. S. (2005). Cardiac lymphoma and pericardial effusion in dogs:12 cases (1994-2004). Journal of the American Veterinary Medical Association, 9(9), 1449-1453. http://dx.doi.org/10.2460/javma.2005.227.1449. PMid:16279390.

Mackey, L. (1975). Feline leukaemia virus and its clinical effects in cats. The Veterinary Record, 96(1), 5-11. http:/l dx.doi.org/10.1136/vr.96.1.5. PMid:163515.

Ménard, M., Fontaine, M., \& Morin, M. (1986). Fine needle aspiration biopsy of malignant tumors in dogs and cats: a report of 102 cases. The Canadian Veterinary Journal. La Revue Veterinaire Canadienne, 27(12), 504510. PMid:17422728.

Morrison, W. B. (2005). Lymphoma in dogs and cats (124 p.). Jackson: Teton NewMedia.

Sherding, R. G. (2008). Vírus da leucemia felina. In S. J. Birchard \& R. G. Sherding. Manual Saunders clínica de pequenos animais (3. ed., pp. 117-127). São Paulo: Roca, 2008.

Sims, C. S., Tobias, A. H., Hayden, D. W., Fine, D. M., Borjesson, D. L., \& Aird, B. (2003). Pericardial effusion due primary cardiac lymphosarcoma in a dog. Journal of Veterinary Internal Medicine, 17(6), 923-927. http://dx.doi. org/10.1111/j.1939-1676.2003.tb02534.x. PMid:14658732.

Souza, H. J. M. (2013). Efusão pleural em gatos. Vital Dog. Retrieved in 2018, June 10, from http://wwwvitaldog. com.br/artigos/EFUSAOPLEURALEMGATOS.pdf

Sparkes, A., \& Papasouliotis, K. (2012). Feline retrovirus infections. In Day M. J. \& Kohn B. BSAVA manual of canine and feline haematology and transfusion medicine (2nd ed., pp. 149-157). Gloucester: British Small Animal Veterinary Association. http://dx.doi.org/10.22233/9781905319732.17.

Taylor, S. S., Goodfellow, M. R., Browne, W. J., Walding, B., Murphy, S., Tzannes, S., Gerou-Ferriani, M., Schwartz, A., \& Dobson, J. M. (2009). Feline extranodal lymphoma: response to chemotherapy and survival in 110 cats. The Journal of Small Animal Practice, 50(11), 584-592. http://dx.doi.org/10.1111/j.1748-5827.2009.00813.x. PMid:19891724.

Tilley, L. P., \& Goodwin, J. K. (2002). Manual de cardiologia para cães e gatos (3. ed., 504 p.). São Paulo: Roca.

Vail, D. M. (2007). Feline lymphoma and leukemia. In D. M. Vail \& S. J. Withrow. Withrow and Macewen's small animal clinical oncology (4th ed., pp. 31-50). Missouri: Saunders Elsevier.

Vail, D. M., Moore, A. S., Ogilvie, G. K., \& Volk, L. M. (1998). Feline lymphoma (145cases): proliferation indices, cluster of differentiation 3 immunoreactivity, and their association with prognosis in 90 cats. Journal of Veterinary Internal Medicine, 12(5), 349-354. http://dx.doi.org/10.1111/j.1939-1676.1998.tb02134.x. PMid:9773411.

Vonderhaar, M. A., \& Morrison, W. B. (1998). Lymphosarcoma. In W. B. Morrison. Cancer in dogs and cats: medical and surgical management (pp. 667-695). Philadelphia: Lippincott.

Withrow, S. J. (2007). Why worry about cancer in pets? In D. M. Vail \& S. J. Withrow. Withrow and Macewen's small animal clinical oncology (4th ed., pp. xv-xvii). Missouri: Saunders Elsevier. http://dx.doi.org/10.1016/ B978-072160558-6.50003-4. 